\title{
First 100 Days of the COVID-19 Pandemic: An Evaluation of Preventive Measures Taken By Countries
}

\author{
COVID-19 Pandemisinin IIlk 100 Günü: Ülkeler \\ Tarafından Alınan Önlemlerin Değerlendirilmesi
}

\begin{abstract}
Aim: The aim of the study is, evaluation of the pandemic data of and measures taken by 20 countries with the highest reported number of cases in the first 100 days of the pandemic, in terms of demographic data and healthcare resources.

Materials and Methods: The data used in the study were obtained from ECDC, OECD and Oxford COVID-19 Government Response Tracker. The countries were categorized into two groups, early-onset and late-onset countries, in terms of their date of first confirmed cases and Stringency Index (SI) were calculated.

Results: United States has the highest number of cases $(432,132)$. France was the first country to report death, outside of China. Top three countries with the highest Case Fatality Rate (CFR) are France (13.25), Italy (12.67) and United Kingdom (11.69). There was a strong negative correlation between "total death/total population proportion" and the intensive care unit bed per million population ( $r=-0.720 ; p=0.008$ ). The "proportion of $\geq 65$ age" was found to have a moderately positive correlation with "total case / total population proportion" as well as "total death / total population proportion" $(r=0.687 ; p=0.001 ; r=0.635 ; p=0.003$, respectively). In the late-onset countries, the logarithmic growth of both case and death numbers is faster than the early-onset countries. The $\mathrm{SI}$ is higher in late-onset counties both on the dates of logarithmic growth in the number of cases and on the 100th day of the pandemic. Restrictions on international travel is the earliest measure taken by countries. Turkey is the only country to implement 3 of 9 measures before its first case.

Discussion and Conclusion: The first encounter dates of countries with the pandemic are important in terms of preparedness. Despite, late-onset countries benefited from the experiences of early-onset countries and implemented measures, the emergence of cases and deaths could not be prevented. Moreover, the increase in cases and deaths was faster. Countries which have more elderly population are affected more adversely. Because the transmission patterns of the pandemic are related with country-specific characteristics, all variables that have an impact on the pandemic should be considered.
\end{abstract}

Key Words: COVID19; SARS-CoV-2; Stringency Index; preventive measures

Öz

Amaç: Bu çalıșmanın amacı, pandeminin ilk 100 gününde en çok vaka görülen 20 ülkenin salgın verileri ve önleyici müdahalelerinin, demografik ve sağlık hizmeti kapasitesi verileriyle birlikte incelenmesidir.

Gereç ve Yöntemler: Araștırmada ECDC'nin salgın verileri, OECD'nin sosyodemografik ve sağlık hizmeti kapasitesi verileri, Oxford COVID-19 Government Response Tracker veritabanının ise önlemlere dair verileri ve 'Stringency Index' puanı kullanılmıștır. Salgının bașlangıcından itibaren ilk 1 ay içerisinde vaka görülen ülkeler erken bașlangıçlı, diğerleri geç bașlangıçlı olarak tanımlanmıștır.
Omer Atac ${ }^{1}$, Sabanur Cavdar ${ }^{2}$, Ayse Zulal Tokac ${ }^{3}$

Istanbul Medipol University, School of Medicine, Department of Public Health, Istanbul, Turkey

2 Istanbul Umraniye District Health Directorate, Istanbul, Turkey

3 Istanbul University, Institute of Health Sciences, Department of Public Health, Istanbul, Turkey

Received/Gelis : 06.05.2020 Accepted/Kabul : 21.05.2020

DOI: 10.21673/anadoluklin.733245

Corresponding author/ Yazıșma yazarı Ayșe Zülal Tokaç

Tahtakale Mh. Faruk Nafız Camlıbel Cd. 7/1 Daire:4 Esenyurt, Istanbul

E-mail: azulaltokac@gmail.com

\section{ORCID}

Ömer Ataç: 0000-0001-8984-9673

Sabanur Çavdar: 0000-0001-5490-6877 Ayșe Zülal Tokaç: 0000-0002-9235-5647 
Bulgular: Ilk 100 gün itibariyle toplam vaka sayısının en yüksek olduğu ülke ABD'dir (432.132). Cin'den sonra ilk ölüm bildiren ülke Fransa'dır. Vaka ölüm oranının en yüksek olduğu ülkeler Fransa $(13,25)$, Italya $(12,67)$ ve Birleșik Krallık'tır $(11,69)$. Ülkelerin, "toplam ölüm/toplam nüfus oranı" ile nüfus bașına düșen yoğun bakım yatağı arasında negatif yönde güçlü bir ilișki saptanmıștır ( $r=-0,720 ; p=0,008) .65$ yas ve üzeri nüfus oranı ile "toplam vaka/toplam nüfus oranı" ve "toplam ölüm/toplam nüfus oranı" arasında pozitif yönde orta derecede bir ilișki bulunmuștur ( $r=0,687 ; p=0,001$; $r=0,635 ; p=0,003)$. Geç gruptaki ülkelerde hem vaka hem de ölüm sayılarının logaritmik artıșı erken grup ülkelere göre istatistiksel olarak anlamlı düzeyde daha hızlıdır. Stringency Index, geç grup ülkelerde hem vaka sayısının logaritmik artış tarihlerinde hem de pandeminin 100. gününde daha yüksektir. Ülkelerin en erken aldıkları önlem, uluslararası seyahatle- rin kısıtlanmasıdır. Türkiye, ilk vakasından önce en çok önlem alan ülke olup, dokuz önlemin üçünü uygulamıștır.

Sonuç: Ülkelerin salgına yakalandıkları tarih, salgına karşı hazırlıklı olunması açısından önemlidir. Salgının geç başladığı ülkeler, erken bașlayan ülkelerin yașadığı tecrübeleri dikkate alarak önlemleri daha sıkı tutmalarına rağmen bu ülkelerde de vaka ve ölümlerin önüne geçilememiștir. Üstelik vaka ve ölümlerde artış erken grup ülkelere göre daha hızlı olmuștur. Bununla birlikte yașlı nüfusun daha șiddetli etkilendiği bir sağlık sorununda, yașlı nüfus yüzdesi yüksek ülkeler daha olumsuz etkilenmektedir. Pandeminin yayılımı ve seyrinde ülkelere özgü dinamikler olması nedeniyle, tüm sürecin anlaşılabilmesi salgını etkileyen tüm faktörlerin göz önünde bulundurulmasını gerekmektedir.

Anahtar Sözcükler: COVID19; SARS-CoV-2; Stringency Index; önleyici tedbirler

\section{INTRODUCTION}

On December 31, 2019, the World Health Organization's (WHO) China Country Office reported cases of pneumonia of unknown etiology. On January 7,2020 , it was determined that the etiological agent was a new type of coronavirus that has never been seen in humans before (1). The disease was later named as COVID-19 (2). Within a month after December 31, the formally acknowledged start date of the outbreak, case numbers increased rapidly, with more than 10,000 cases reported in 23 countries (3). WHO declared the outbreak as a pandemic on March 11, where a total of 118,000 cases and 4,291 deaths were reported in 118 countries (4). As of April 08, the 100th day of the epidemic, it had reached 210 countries/regions with the total number of confirmed cases reaching $1,436,198$, the number of deaths exceeding 85,521 and 4 countries outpacing China in the number of cases reported (5).

In the fight against the COVID-19 pandemic, WHO has advised the countries to increase their preparations for the epidemic, put emphasis on case detection, follow-up and treatment, take measures to reduce the transmission and be open to innovation and learning (4). Non-pharmaceutic interventions to prevent the spread of the outbreak contains public information and communication campaigns, isolation of the cases and quarantine of the contacts, personal and social hygiene measures such as handwashing, household disinfection and wearing masks in public areas, social distancing measures such as stay-at-home calls, restrictions or bans on public gatherings, curfews for certain age groups or whole community, closing schools and workplaces, applying cordon sanitaire and travel restriction measures such as inter-country or intra-country travel bans $(6,7)$. The effect of quarantine measures on reducing the spread of the epidemic is demonstrated by modeling studies. Interventions such as school closures, travel restrictions and social distancing alongside quarantine measures are shown to strengthen this impact $(8,9)$. WHO recommends that each country shall adapt these measures according to their own case numbers and taking economic and social factors into account. In this regard, since the onset of the outbreak, countries and regions have implemented various interventions at different times and in different forms $(10,11)$.

In this study, we aimed to evaluate the pandemic data of and measures taken by 20 countries with the highest reported number of cases in the first 100 days of the pandemic, in terms of demographic data and healthcare resources.

\section{MATERIALS AND METHODS}

Our study is a cross-sectional study which is conducted between April 10-30, 2020. At the 100th day of the pandemic (April 8, 2020), the top 20 countries in the total confirmed case rankings among 
Table 1: OxCGRT Indicators

\begin{tabular}{|c|c|}
\hline ID & Name \\
\hline \multicolumn{2}{|c|}{ Containment and closure } \\
\hline $\mathrm{C} 1^{*}$ & School closing \\
\hline $\mathrm{C} 2^{*}$ & Workplace closing \\
\hline $\mathrm{C}^{*}$ & Cancel public events \\
\hline $\mathrm{C} 4^{*}$ & Restrictions on gathering size \\
\hline $\mathrm{C}^{*}$ & Close public transport \\
\hline $\mathrm{C} 6^{*}$ & Stay at home requirements \\
\hline $\mathrm{C}^{*}$ & Restrictions on internal movement \\
\hline $\mathrm{C} 8^{*}$ & Restrictions on international travel \\
\hline \multicolumn{2}{|c|}{ Economic response } \\
\hline E1 & Income support \\
\hline E2 & Debt/contract relief for households \\
\hline E3 & Fiscal measures \\
\hline $\mathrm{E} 4$ & Giving international support \\
\hline \multicolumn{2}{|c|}{ Health systems } \\
\hline $\mathrm{H} 1^{*}$ & Public information campaign \\
\hline $\mathrm{H} 2$ & Testing policy \\
\hline H3 & Contact tracing \\
\hline $\mathrm{H} 4$ & Emergency investment in healthcare \\
\hline H5 & Investment in COVID-19 vaccines \\
\hline \multicolumn{2}{|c|}{ Miscellaneous } \\
\hline M1 & Other responses \\
\hline
\end{tabular}

${ }^{*}$ Indicators considered in the stringency index calculation.

Table 2: Groups of countries in terms of the date of the first confirmed case

\begin{tabular}{|l|l|}
\hline Groups & \multicolumn{1}{|c|}{ Countries } \\
\hline Early-onset & $\begin{array}{l}\text { Canada, China, France, Germany, Italy, Russia, } \\
\text { Spain, South Korea, Sweden, United Kingdom } \\
\text { (UK), United States (USA) }\end{array}$ \\
\hline Late-onset & $\begin{array}{l}\text { Austria, Belgium, Brazil, Iran, Israel, Netherlands, } \\
\text { Portugal, Sweden, Switzerland, Turkey }\end{array}$ \\
\hline
\end{tabular}

worldwide were included in the study (5). The case and death rate data of countries were recorded as one day before when they were published on WHO and European Centre for Disease Prevention and Control (ECDC). For example, while the first confirmed cases were announced on March 11, it was recorded as March 12 in the WHO and the ECDC reports $(5,12)$.

The data used in the research were obtained from various sources that are open and free of charge on the internet. The most updated sociodemographic and healthcare resources data of the countries are selected from the Organisation for Economic Cooperation and Development (OECD) database (13). United Nations'(UN) database was used for data of non-OECD countries such as China, Russia and Brazil (14). The data of countries' preventive measures were extracted from the database of Oxford COVID-19 Government Response Tracker (OxCGRT-20) (15). This database was formed by a working group at the University of Oxford to collect information on common policy responses, scores the stringency of such measures, and aggregates these into a Stringency Index (SI). The data searched by the working group via internet is transferred to the OxCGRT-20 database. The measures taken by the countries are evaluated with 18 different headings (Table 1) (16).

Stringency Index is calculated using only the policy indicators $\mathrm{C} 1-\mathrm{C} 8$ and $\mathrm{H} 1$. The value of the index on any given day is the average of nine subindices pertaining to the individual policy indicators, each taking a value between 0 and 100 .

Independent variables of the study are sociodemographic and healthcare indicators and confirmed case-death numbers, dependent variable is Stringency Index.

The countries were categorized into two groups in terms of their date of first confirmed cases and this grouping is based on the first confirmed case date of China December 31, 2020. Those countries who encountered with first confirmed cases within the first month (January) are identified as early-onset countries and those who encountered with first confirmed cases after the first month (after January) are identified as late-onset countries (Table 2).

In the first part of the study, the relationship between pandemic data of the countries such as casedeath numbers, Case Fatality Rate (CFR), "total case / total population proportion" and "total death / total population proportion" and sociodemographic and health care resources data were examined. In the second part, the rates of cases and deaths in countries were evaluated according to the early and late-onset of the outbreak. In the third part, the Stringency Index scores of the countries were analyzed in terms of the country groups and logarith- 
mic growth of the pandemic. The implementation dates of the 9 measures (C1-C8 and $\mathrm{H} 1$ ) that constitute the SI of the countries were evaluated according to the first case date in the country, lastly.

\section{Statistical analysis}

After the data was combined and corrected in Microsoft Office 365 Excel, it was transferred to SPSS 24.0 for analyses. Mean, standard deviation, median, minimum, maximum, frequencies and percentages are calculated for descriptive statistics. MannWhitney $U$ test was used to analyze the differences between the groups. Correlation coefficients was calculated with Spearman test. The statistically significant level was accepted as $\mathrm{p}<0.05$.

Since this study is conducted through open data that are accessible through publicly open data, any ethics committee approval was not taken.

\section{RESULTS}

Among the countries included in the study, the country with the longest life expectancy at birth is Switzerland (83.6) and the shortest is Russia (72.4) (Table 3). 14 of the 20 countries have a life expectancy over 80 years. According to population distribution by age, the youngest countries (top countries according $<15$ years population percentage) are Israel (27.89\%), Iran (24.33\%) and Turkey (24.29\%); the oldest countries (top countries according $\geq 65$ years population percentage) are Italy (23.01\%), Netherlands (22.36\%) and Germany (21.56\%) respectively. Based on Human Development Index (HDI) rankings, while Switzerland has the highest rank (0.944), China has the lowest (0.752).

When healthcare resource indicators are examined, Austria (5.18), Portugal (4.97) and Switzerland (4.30) have the highest number of doctors per thousand population whereas China (1.98), Turkey (1.87) and Iran (1.58) have the lowest. In 8 countries, this proportion is lower than 3 . The countries with the highest number of hospital beds per thousand population are South Korea (12.27), Russia (8.2) and Germany (8.0) while Iran has the lowest number (1.50). Turkey (46.1) and Germany (33.9) have the greatest number of intensive care unit (ICU) beds per 100.000 population whereas Italy (8.6) and the Netherlands (6.7) have the least. In the number of CT devices per million population, USA has the highest rank with 42.6 and Iran has the lowest with 6.5 .

Among these 20 countries, the first cases outside of China were recorded in South Korea on January 19 and in the United States on January 20 (Table 4). Out of 20 countries excluding China, France was the first country to report a COVID-19 related death on February 14 while Russia was the last country to report it on March 26. Iran is the only country in the late-onset group where the first death has occurred in February as well as being the only country where the first case and first death were reported on the same day. Turkey is the last country to report its first case among all 20 countries. Top three countries with the highest CFR are France (13.25), Italy (12.67) and United Kingdom (11.69) whereas the countries with the lowest CFR are Russia (0.73), Israel (0.75) and Germany (1.95). South Korea and Germany are early-onset countries with CFRs below 2. Meanwhile, The Netherlands, Spain, Belgium, Sweden, Iran and Brazil are late-onset countries with CFRs over 5. According to the number of confirmed cases by the 100th day of the pandemic, USA has the highest number of cases $(432,132)$ and Sweden has the lowest $(8,419)$.

When the correlation between healthcare resources of countries and essential pandemic indicators were analyzed, no significant relationship was found between healthcare indicators and CFR. On the other hand, there was a strong negative correlation between "total death / total population proportion" and the intensive care unit beds per 100.000 population $(\mathrm{n}=12 ; \mathrm{r}=-0.720 ; \mathrm{p}=0.008)$.

In the correlation analysis conducted to determine the relationship between the demographic data and pandemic data of the countries; the population percentage between the ages of 15-64 was found to have a moderately negative correlation with "total case / total population proportion" and a weakly negative correlation with "total death / total population proportion" $(\mathrm{r}=-0.550, \mathrm{p}=0.012 ; \mathrm{r}=$ $-0.487, \mathrm{p}=0.030$, respectively). 


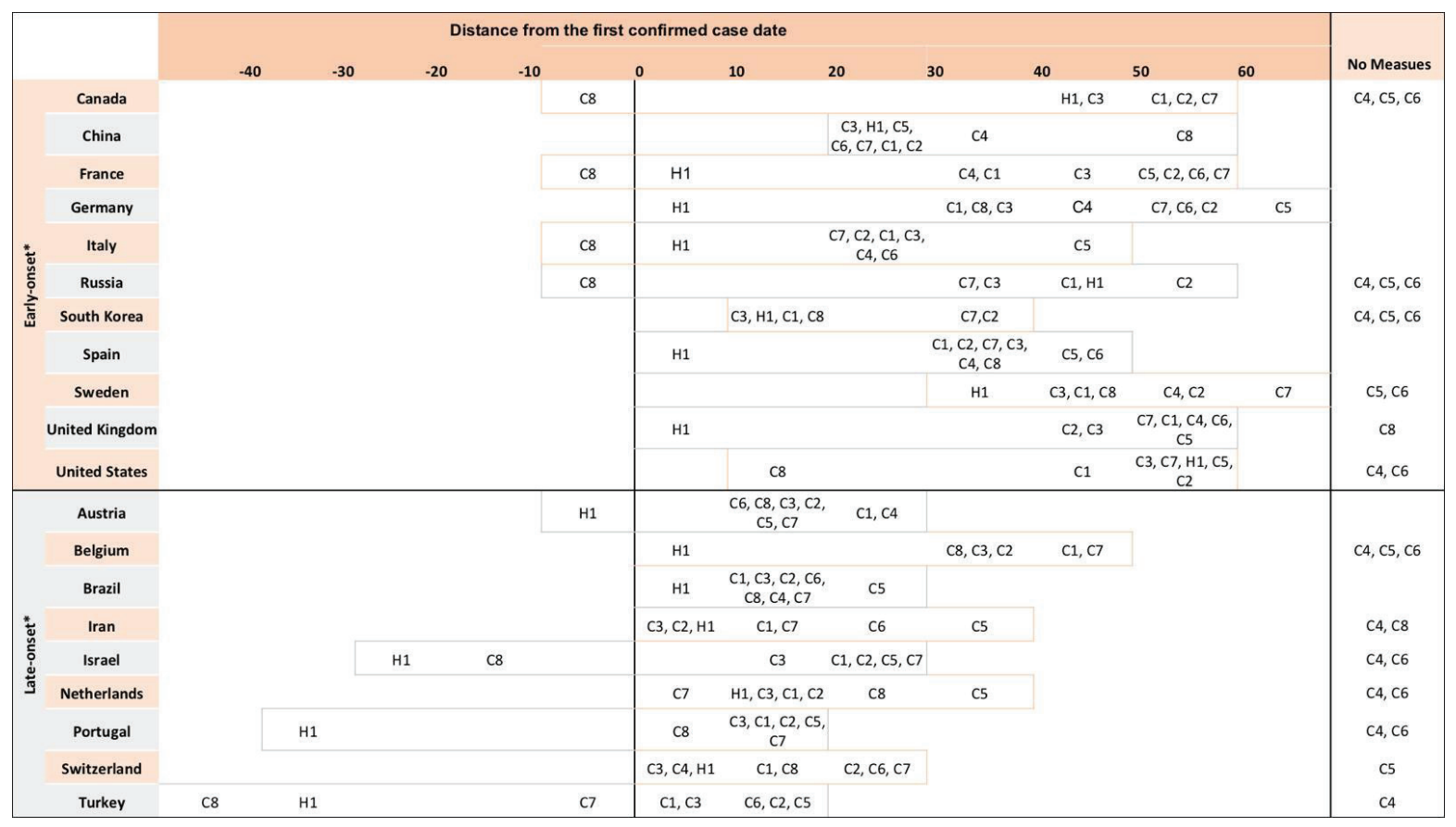

Figure 1: Evaluation of the measures taken by countries in terms of the first confirmed case date

$\left({ }^{*}\right.$ Regardless of the level of measures taken, the first date of implementation was considered. Countries are listed alphabetically, C1: School closing, C2: Workplace closing, C3: Cancel public events, C4: Restrictions on gathering size, C5: Close public transport, C6: Stay at home requirements, C7: Restrictions on internal movement, C8: Restrictions on international travel, H1: Public information campaign)

The population percentage of people aged 65 and above was found to have a moderately positive correlation with "total case / total population proportion" as well as "total death / total population proportion" $(\mathrm{r}=0.687 ; \mathrm{p}=0.001 ; \mathrm{r}=0.635 ; \mathrm{p}=$ 0.003 , respectively). A moderately possitive correlation was found between life expectancy at birth and both "total case / total population" and "total death / total population" proportions $(\mathrm{r}=0.608 ; \mathrm{p}=0.004$; $\mathrm{r}=0.657 ; \mathrm{p}=0.002$, respectively). The HDI have a moderately positive correlation with "total case / total population proportion" ( $\mathrm{r}=0.542 ; \mathrm{p}=0.014)$.

There was no significant difference regarding the distribution of demographic data and health care resources between the early-onset and late-onset groups.

In the late-onset countries, the logarithmic growth of the epidemic is faster than in the earlyonset countries, and the difference is significant at all milestones (Table 5). The duration to reach the 1,000 th cases is $42.5 \pm 10.0$ days in the early-onset countries and $21.3 \pm 9.8$ days in the late-onset coun- tries. In the late-onset group, the time between First10 th and 10th-100th cases is significantly shorter. In the late-onset group, the duration between 1st-10th cases is $7.6 \pm 8.5$ and between 10th-100th cases is $6.4 \pm 2.8$ days while in the early-onset group, the time between first-10th cases is $19.4 \pm 10.7$ and the time between 10th-100th cases is $15.2 \pm 8.8$ days $(\mathrm{p}=0.020$ and $\mathrm{p}=0.031$, respectively). When the logarithmic growth rate of deaths is analyzed, it is determined that the average number of days in the late-onset group is shorter than the early-onset group and the difference in all increases before 1000th deaths is significant.

When the Stringency Index averages are compared according to the dates when the cases were detected, the late-onset countries have a higher average in all milestones than the early-onset countries (Table 6). The average of SI is $44.01 \pm 19.57$ in the early-onset countries and $69.68 \pm 17.80$ in the late-onset countries for the dates of 1000th cases in each country $(p=0.007)$. As of the 100th day of the pandemic, it was $76.19 \pm 13.82$ in the early-onset 
Table 3. Sociodemographic and health care resources data of the countries

\begin{tabular}{|c|c|c|c|c|c|c|c|c|c|c|c|c|}
\hline Countries $^{*}$ & $\begin{array}{l}\text { Life expectancy } \\
\text { at birth }\end{array}$ & Population, total & $\begin{array}{c}\text { Population ages } \\
0-14 \text { (\% of total } \\
\text { population) }\end{array}$ & $\begin{array}{c}\text { Population ages } \\
15-64 \text { (\% of total } \\
\text { population) }\end{array}$ & $\begin{array}{c}\text { Population ages } \\
\geq 65 \text { (\% of total } \\
\text { population) }\end{array}$ & HDI & $\begin{array}{c}\text { Physicians } \\
\text { (per 1,000 } \\
\text { population) }\end{array}$ & $\begin{array}{c}\text { Nurses } \\
\text { (per 1,000 } \\
\text { population) }\end{array}$ & $\begin{array}{c}\text { Hospital beds } \\
\text { (per 1,000 } \\
\text { population) }\end{array}$ & $\begin{array}{c}\text { ICU beds } \\
\text { (per 100,000 } \\
\text { population) }\end{array}$ & $\begin{array}{c}\text { CT scanners, } \\
\text { total (per } \\
1,000,000 \\
\text { population) }\end{array}$ & $\begin{array}{c}\text { CT exams, } \\
\text { total (per 1,000 } \\
\text { population) }\end{array}$ \\
\hline Austria & 81.7 & $8,954,000$ & 14.36 & 66.56 & 19.08 & 0.908 & 5.18 & 6.85 & 7.37 & 17.4 & 28.6 & 149.6 \\
\hline Belgium & 81.6 & $11,543,000$ & 17.05 & 63.93 & 19.02 & 0.916 & 3.08 & 10.96 & 5.66 & - & 23.0 & 200.5 \\
\hline Brazil & 75.7 & $211,051,000$ & 21.01 & 69.74 & 9.25 & 0.759 & 2.16 & 10.11 & 2.20 & - & 15.4 & - \\
\hline Canada & 82.0 & $37,412,000$ & 15.85 & 66.51 & 17.65 & 0.926 & 2.65 & 9.96 & 2.52 & 12.9 & 15.3 & 152.9 \\
\hline China & 75.4 & $1,433,785,000$ & 17.80 & 70.72 & 11.47 & 0.752 & 1.98 & 2.66 & 4.20 & - & - & - \\
\hline France & 82.6 & $65,130,000$ & 17.80 & 61.81 & 20.39 & 0.901 & 3.16 & 10.48 & 5.98 & 16.3 & 17.4 & 189.7 \\
\hline Germany & 81.1 & $83,517,000$ & 13.80 & 64.64 & 21.56 & 0.936 & 4.25 & 12.93 & 8,00 & 33.9 & 35.1 & 148.5 \\
\hline Iran & 76.5 & $75,332,000$ & 24.33 & 71.48 & 4.19 & 0.798 & 1.58 & 0.44 & 1.50 & - & 6.5 & - \\
\hline Israel & 82.6 & $8,520,000$ & 27.89 & 59.91 & 12.21 & 0.903 & 3.14 & 5.08 & 3.02 & - & 9.5 & 145.2 \\
\hline Italy & 83.0 & $60,551,000$ & 13.17 & 63.82 & 23.01 & 0.880 & 3.99 & 5.80 & 3.18 & 8.6 & 34.7 & 89.9 \\
\hline Netherlands & 81.8 & $10,226,000$ & 13.25 & 64.38 & 22.36 & 0.931 & 3.58 & 10.88 & 3.32 & 6.7 & 13.5 & 94 \\
\hline Portugal & 81.5 & $51,225,000$ & 12.75 & 72.19 & 15.06 & 0.847 & 4.97 & 6.70 & 3.39 & - & 24.0 & 188.9 \\
\hline Russia & 72.4 & $145,873,000$ & 18.15 & 66.75 & 15.09 & 0.816 & 3.75 & 8.54 & 8.20 & - & 13.6 & - \\
\hline South Korea & 82.7 & $17,096,000$ & 15.88 & 64.51 & 19.61 & 0.903 & 2.34 & 6.91 & 12.27 & 10.6 & 38.2 & 204.6 \\
\hline Spain & 83.4 & $46,735,000$ & 14.58 & 65.78 & 19.65 & 0.891 & 3.88 & 5.74 & 2.97 & 9.7 & 18.6 & 114.9 \\
\hline Sweden & 82.5 & $10,038,000$ & 17.63 & 62.16 & 20.20 & 0.933 & 4.12 & 10.90 & 2.22 & - & 18.5 & - \\
\hline Switzerland & 83.6 & $8,592,000$ & 14.94 & 66.21 & 18.84 & 0.944 & 4.30 & 17.23 & 4.53 & 11.8 & 39.3 & 109.9 \\
\hline Turkey & 78.1 & $83,428,000$ & 24.29 & 66.98 & 8.73 & 0.791 & 1.87 & 2.07 & 2.81 & 46.1 & 14.8 & 206.6 \\
\hline United Kingdom & 81.3 & $67,529,000$ & 17.70 & 63.80 & 18.51 & 0.922 & 2.81 & 7.83 & 2.54 & 10.5 & 9.4 & 92.3 \\
\hline United States & 78.6 & $329,065,000$ & 18.55 & 65.24 & 16.21 & 0.924 & 2.61 & 11.74 & 2.77 & 25.8 & 42.6 & 255.7 \\
\hline
\end{tabular}

group and $82.03 \pm 5.96$ in the late-onset group. According to the time elapsed between the case increases, in the period from the 1000th case to the 10,000 th case, the SI increase was $33.11 \pm 19.85$ in the early-onset group and $11.07 \pm 12.84$ in the lateonset group $(\mathrm{p}=0.021)$. Also there were negative correlation between the SI scores of the 1000th case day with the total number of cases in the 100th day, and with the CFR value of the 100th day $(\mathrm{r}=-0,514$; $\mathrm{p}=0.021 ; \mathrm{r}=-0.466 ; \mathrm{p}=0.039$, respectively).

When the dates that the early-onset and lateonset countries took nine measures compared to the first case dates, it was found that late-onset countries took the measures in a shorter time (Figure 1). Of these, C1, C2, C3, C4, C5, C6, C7 measures were found to be taken in a statistically significantly shorter time period $(\mathrm{p}=0.002 ; \mathrm{p}=<0.001$; $\mathrm{p}=0.001 ; \mathrm{p}=0.017 ; \mathrm{p}=0.004 ; \mathrm{p}=0.017 ; \mathrm{p}=0.001$, respectively). 4 early-onset countries took measure C8 (restrictions on international travel) before their first cases were reported. 5 early-onset countries and 2 late-onset countries implemented all 9 measures. $\mathrm{C} 1, \mathrm{C} 2, \mathrm{C} 3, \mathrm{C} 7$ and $\mathrm{H} 1$ are common measures taken by all countries. The $\mathrm{C} 4$ measure is not taken in 10 countries, the $\mathrm{C} 6$ measure in 9 countries, the $\mathrm{C} 5$ measure in 6 countries and the C8 measure in 2 countries. Turkey is the only country to implement 3 of 9 precautions before its first case. It is also the country that acts earliest in school closures (day 5), restricting domestic mobility (day -2) and limiting international travel (day -47).

\section{DISCUSSION AND CONCLUSION}

The COVID-19 pandemic has adversely influenced the whole world in so many ways and its transmission patterns tend to differ from one country to another. Countries can be examined in terms of indicators regarding the pandemic such as date of the first confirmed cases, the numbers of total cases, deaths, tests, critical ill, recovered cases and their rates, and other logarithmic variables. In this study, we analyzed the top 20 countries according to total number of confirmed cases within the first 100 days and evaluate the data regarding the pandemic and countries' preventive measures in terms of demographic and healthcare resources data.

As of 100 days after the first emergence of the pandemic, the top 20 countries consist of developed and developing countries. Countries with higher ranks in terms of demographic and health resources, the total number of cases is expected to be higher 
Table 4: Essential pandemic data of the countries April 8, 2020

\begin{tabular}{|c|c|c|c|c|c|c|}
\hline Countries $^{*}$ & Group & Number of cases & $\begin{array}{c}\text { Number of } \\
\text { deaths }\end{array}$ & CFR & $\begin{array}{l}\text { Date of the first } \\
\text { case }\end{array}$ & $\begin{array}{c}\text { Date of the first } \\
\text { death }\end{array}$ \\
\hline Austria & $\mathrm{L}$ & 12,969 & 273 & 2.11 & $25 \mathrm{Feb}$ & $12 \mathrm{Mar}$ \\
\hline Belgium & $\mathrm{L}$ & 23,403 & 2,240 & 9.57 & $3 \mathrm{Feb}$ & $11 \mathrm{Mar}$ \\
\hline Brazil & $\mathrm{L}$ & 15,297 & 800 & 5.23 & $25 \mathrm{Feb}$ & 17 Mar \\
\hline Canada & $\mathrm{E}$ & 19,274 & 435 & 2.26 & 25 Jan & $9 \mathrm{Mar}$ \\
\hline China & $\mathrm{E}$ & 82,870 & 3,339 & 4.03 & $31 \mathrm{Dec}$ & 10 Jan \\
\hline France & $\mathrm{E}$ & 82,048 & 10,869 & 13.25 & $24 \operatorname{Jan}$ & $14 \mathrm{Feb}$ \\
\hline Germany & $\mathrm{E}$ & 108,202 & 2,107 & 1.95 & 28 Jan & 9 Mar \\
\hline Iran & $\mathrm{L}$ & 64,586 & 3,993 & 6.18 & $19 \mathrm{Feb}$ & $19 \mathrm{Feb}$ \\
\hline Israel & $\mathrm{L}$ & 9,404 & 71 & 0.75 & $21 \mathrm{Feb}$ & $20 \mathrm{Mar}$ \\
\hline Italy & $\mathrm{E}$ & 139,422 & 17,669 & 12.67 & 30 Jan & $22 \mathrm{Feb}$ \\
\hline Netherlands & $\mathrm{L}$ & 20,549 & 2,248 & 10.94 & $27 \mathrm{Feb}$ & $6 \mathrm{Mar}$ \\
\hline Portugal & $\mathrm{L}$ & 13,141 & 380 & 2.89 & $2 \mathrm{Mar}$ & $17 \mathrm{Mar}$ \\
\hline Russia & $\mathrm{E}$ & 8,672 & 63 & 0.73 & 31 Jan & $26 \mathrm{Mar}$ \\
\hline Spain & $\mathrm{E}$ & 146,690 & 14,555 & 9.92 & 31 Jan & $4 \mathrm{Mar}$ \\
\hline South Korea & $\mathrm{E}$ & 10,423 & 204 & 1.96 & 19 Jan & $20 \mathrm{Feb}$ \\
\hline Sweden & $\mathrm{E}$ & 8,419 & 687 & 8.16 & 31 Jan & $11 \mathrm{Mar}$ \\
\hline Switzerland & $\mathrm{L}$ & 22,710 & 705 & 3.10 & $25 \mathrm{Feb}$ & $5 \mathrm{Mar}$ \\
\hline Turkey & $\mathrm{L}$ & 38,226 & 812 & 2.12 & $11 \mathrm{Mar}$ & $18 \mathrm{Mar}$ \\
\hline United Kingdom & $\mathrm{E}$ & 60,733 & 7,097 & 11.69 & 30 Jan & $5 \mathrm{Mar}$ \\
\hline United States & $\mathrm{E}$ & 432,132 & 14,817 & 3.43 & 20 Jan & $29 \mathrm{Feb}$ \\
\hline
\end{tabular}

${ }^{\star}$ Countries are listed alphabetically, E: Early-onset. L: Late-onset. CFR: Case fatality rate

as well. The higher number of cases are related to their cosmopolitan features since those countries tend to have more international mobility due to a wide range of factors such as economy, trade, tourism, and education (17). This increases the probability of transmission of the virus from different nations through individuals. On the other hand, it can be said that less developed countries tend to report much less than their actual number of cases because of the inefficiency of health systems and the weakness of surveillance systems (18). Furthermore, it is probable to not have received any information from certain countries that are closed to the global world. For instance, the number of cases were reported as zero for North Korea and Turkmenistan in the 100th day of the pandemic (5).

Struggling with the pandemic has two main pillars. The surveillance and the management of cases and the related contacts in their household are highly crucial to bring the process under control and to prevent further spread of the pandemic (19). It is also important that when it is necessary, confirmed cases should be able to benefit from the health ser- vices for recovery and survival. Depending on the severity of symptoms, cases are being examined at home or hospitals. The latter group receives treatment in hospitals either in service or intensive care units, because of these situations, the indicators which show the healthcare resources of a country such as the numbers of doctors, nurses, hospital beds and intensive care unit beds per population become important. Unless a vaccine is invented against the virus, it is very unlikely to suppress the pandemic completely and the possible biggest challenge that countries will face is whether they will experience a need for health service which is over the capacity of their health systems (20). Unfortunately, countries such as Italy where the number of cases was exponentially increasing have already experienced this problem with a scarcity of equipments such as service and intensive care beds, and even ventilators (21). Due to the limitations regarding the reliability and consistency of diagnostic tests, those patients who have negative PCR, but still show symptoms and CT sign that is matched with the COVID-19 are also treated as positive cases in some countries 
Table 5: Comparison of logarithmic growth duration of cases and deaths by country groups

\begin{tabular}{|c|c|c|c|c|c|c|c|}
\hline & \multicolumn{3}{|c|}{ Early-onset } & \multicolumn{3}{|c|}{ Late-onset } & \multirow[b]{2}{*}{ p value } \\
\hline & $\mathbf{n}$ & Mean \pm SD & Median (min-max) & $\mathbf{n}$ & Mean \pm SD & Median (min-max) & \\
\hline \multicolumn{8}{|l|}{ Cases (by first case) } \\
\hline 10th case & 11 & $19.4 \pm 10.7$ & $22(0-35)$ & 9 & $7.6 \pm 8.5$ & $4(2-29)$ & 0.020 \\
\hline 100th case & 11 & $34.6 \pm 8.6$ & $35(18-46)$ & 9 & $14.0 \pm 8.3$ & $11(7-32)$ & $<0.001$ \\
\hline 1,000 th case & 11 & $42.5 \pm 10.0$ & $44(24-56)$ & 9 & $21.3 \pm 9.8$ & $18(11-42)$ & 0.001 \\
\hline 10,000 th case & 9 & $53.7 \pm 13.4$ & $55(31-74)$ & 8 & $33.0 \pm 11.1$ & $32(19-55)$ & 0.006 \\
\hline 100,000 th case & 4 & $65 \pm 5.4$ & $64.5(60-71)$ & & & & - \\
\hline \multicolumn{8}{|l|}{ Cases } \\
\hline First to 10 th & 11 & $19.4 \pm 10.7$ & $22(0-35)$ & 9 & $7.6 \pm 8.5$ & $4(2-29)$ & 0.020 \\
\hline 10th to 100th & 11 & $15.2 \pm 8.8$ & $16(2-29)$ & 9 & $6.4 \pm 2.8$ & $7(3-12)$ & 0.031 \\
\hline 100th to 1000 th & 11 & $7.9 \pm 1.7$ & $8(5-10)$ & 9 & $7.3 \pm 1.9$ & $7(4-10)$ & 0.552 \\
\hline 1,000 th to 10,000 th & 9 & $12.9 \pm 9.2$ & $10(7-37)$ & 8 & $12.8 \pm 2.5$ & $13.5(8-15)$ & 0.093 \\
\hline 10,000 th to 100,000 th & 4 & $15.5 \pm 5.4$ & $17(8-20)$ & & & & - \\
\hline \multicolumn{8}{|l|}{ Deaths (by first case) } \\
\hline First death & 11 & $34.3 \pm 12.5$ & $36(10-55)$ & 9 & $15.7 \pm 11.5$ & $15(0-37)$ & 0.003 \\
\hline 10th death & 11 & $41.9 \pm 11.1$ & $43(21-59)$ & 9 & $21.9 \pm 12.1$ & $19(5-44)$ & 0.002 \\
\hline 100th death & 10 & $50.1 \pm 12.4$ & $53.5(27-67)$ & 8 & $28.1 \pm 11.1$ & $27.5(15-50)$ & 0.002 \\
\hline 1,000 th death & 7 & $54.7 \pm 10.7$ & $59(41-66)$ & 3 & $40.0 \pm 16.6$ & $33(28-59)$ & 0.117 \\
\hline 10,000 th death & 4 & $68.0 \pm 9.5$ & $68(58-78)$ & & & & - \\
\hline
\end{tabular}

such as Turkey. Although these individuals are not reported as confirmed cases in the official statistics yet, they receive their treatments in accordance with the same treatment protocols of positive cases (22). Therefore, the number of CT devices becomes another important indicator. Countries tend to differ in terms of the prominent features of their health system capacities. For example, Turkey is placed as second-to-last in the number of doctors per 1000 patients while, it also ranks first in the number of ICU beds, which is an important indicator for case treatment, and second in the number of CT exams.

Since elderly populations tend to be more adversely influenced by the disease, the demographic structures of countries play a crucial role for the progression of the pandemic (23). The case and death numbers per population tend to increase when there is an increase in the proportion of people aged over 65. All four countries (Italy, France, the UK, and Netherlands) which have higher case-fatality rates than $10 \%$ also have a significant proportion of elderly population. In terms of the old-age dependency ratio, Italy ranks first and Netherlands ranks second while France ranks fourth and the UK ranks eleventh. The life expectancy at birth in these countries is over 80 years as well. There are studies re- porting that the incidence of COVID-19 correlates with life expectancy at birth, which is an indicator of development (24). Considering the high ability to tracing and confirming cases in developed countries, it can contribute to the high number of cases in these countries. While Netherlands and Italy are placed among the last two ranks in terms of their ICU bed numbers which is an important indicator for the treatment of elderly population and severe cases, Turkey ranks among the last ones in terms of its case-fatality rates. Nevertheless, it is helpful to remind that the test policies of countries, preventive interventions, and other measures were not considered when these evaluations were conducted. Negative correlation between numbers of ICU beds and number of deaths per population confirms the studies that show the need of intensive care for a certain number of case (25). This also supported the fact that the death rates are getting increased when there is an inadequacy regarding the intensive care unit capacity.

In our study, the reason why there is no relationship between the variables regarding the demography and health service capacity and CFR might be explained that by the fact that every country experienced a different phase of the pandemic on April 
Table 6: Comparison of SI scores and differences between logarithmic growth dates by country groups

\begin{tabular}{|c|c|c|c|c|c|c|c|}
\hline & \multicolumn{6}{|c|}{ Stringency Index } & \multirow[b]{3}{*}{ p value } \\
\hline & \multicolumn{3}{|c|}{ Early-onset } & \multicolumn{3}{|c|}{ Late-onset } & \\
\hline & $\mathbf{n}$ & Mean \pm SD & Median (min-max) & $\mathbf{n}$ & $\operatorname{Mean} \pm$ SD & Median (min-max) & \\
\hline \multicolumn{8}{|l|}{ Cases } \\
\hline 1 st & 11 & $6.41 \pm 7.75$ & $2.86(0-22.86)$ & 9 & $11.43 \pm 12.49$ & $9.52(0-37.14)$ & 0.345 \\
\hline 10th & 11 & $12.92 \pm 12.18$ & $14.29(0-43.10)$ & 9 & $16.51 \pm 9.77$ & $14.29(0-37.14)$ & 0.46 \\
\hline 100th & 11 & $25.73 \pm 20.97$ & $25.71(0-62.86)$ & 9 & $35.90 \pm 18.62$ & $32.14(4.76-65.71)$ & 0.239 \\
\hline 1,000 th & 11 & $44.01 \pm 19.57$ & $38.10(14.29-66.90)$ & 9 & $69.68 \pm 17.80$ & $72.86(32.14-88.81)$ & 0.007 \\
\hline 10,000 th & 9 & $76.43 \pm 10.98$ & $76.43(56.19-92.38)$ & 8 & $78.36 \pm 5.30$ & $78.81(67.86-84.76)$ & 0.847 \\
\hline 100,000 th & 4 & $79.11 \pm 10.19$ & $79.77(68.10-88.81)$ & - & - & - & - \\
\hline 8th April & 11 & $76.19 \pm 13.82$ & $80.00(43.81-92.38)$ & 9 & $82.03 \pm 5.96$ & $81.67(75.71-92.38)$ & 0.402 \\
\hline \multicolumn{8}{|l|}{ Differences } \\
\hline First to 10th & 11 & $6.52 \pm 8.01$ & $2.86(0-20.24)$ & 9 & $5.08 \pm 6.88$ & $0.00(0-17.14)$ & 0.626 \\
\hline 10th to 100th & 11 & $12.81 \pm 12.91$ & $10.47(0-32.14)$ & 9 & $19.39 \pm 12.04$ & $17.85(0-34.28)$ & 0.235 \\
\hline 100th to 1,000 th & 11 & $18.28 \pm 16.35$ & $15.47(0-41.90)$ & 9 & $33.79 \pm 22.34$ & $26.19(0-62.86)$ & 0.127 \\
\hline 1,000 th to 10,000 th & 9 & $33.11 \pm 19.85$ & $29.05(8.34-66.66)$ & 8 & $11.07 \pm 12.84$ & $4.41(0-35.72)$ & 0.021 \\
\hline $\begin{array}{l}10,000 \text { th to } \\
100,000 \text { th }\end{array}$ & 4 & $5.54 \pm 7.56$ & $2.74(0-16.67)$ & - & - & - & - \\
\hline
\end{tabular}

8, 2020 on which the CFR value was measured. For example, while Turkey was in its 29th day after the emergence of first case, China was in its 100th day (Table 4). Furthermore, other indicators which were not considered in this research might affect the CFR as well. We found a negative correlation between the countries Stringency Index scores at the 1000th case's day and the total number of cases in the 100th day and also with the CFR value of the 100th day. This correlation demonstrates that to what extent preventive measures are stringent in the day that the 1000th case is confirmed, the total numbers of cases and CFR in the 100th tend to be less, depending on the former. If the preventive measures are stringent, it is very likely to have less number of cases and also case-fatality rates $(8,9)$.

The pandemic's transmission tends to be different among countries and it is influenced by the factors such as the number of people in cities per square meter, the average number of households, cultural factors, physical contact in daily life, and sincerity. While some countries do not experience any case for a couple of weeks after the first confirmed cases, for instance, the number of confirmed cases for Turkey after the first confirmed case was 100 in the 7 th day and 1000 in the 11th day (26). The first index cases or basic reproduction numbers (R0) within a country are important factors for the transmission of the pandemic (27). According to this, although Turkey had experienced the first case in a late date, it is very likely that there were more than one index cases. Those 372,000 people who came from abroad to Turkey within the first two weeks of March might contribute to these numbers (28). The fact of this opinion should be investigated with epidemiological studies.

The first encounter dates of countries with the pandemic are crucial in terms of taking it serious or being prepared. While it would be more difficult for early-onset countries if their preparations are not adequate, late-onset countries can benefit from the experiences of early-onset countries. Among earlyonset countries, only South Korea was able to keep the total number of cases and death rates low with its intense testing and isolation policies $(29,30)$. Moreover, although it is geographically very close to China, South Korea ranks 17th place in the total number of cases. However, some European countries such as France, Italy, and the UK, as already mentioned in earlier paragraphs, could not show the same success.

On the other hand, while late-onset countries were in an advantaged position in terms of time which enabled them to apply preventive measures more quickly. It is significant to see that late-onset countries still tend to have higher rates of increase 
both for the total number of cases and death rates than early-onset countries. The situations that the index average of late-onset countries based on case numbers is higher than early-onset countries and the difference between them in the 1000th case day is significant demonstrate that late-onset countries took advantage of experiences of early-onset countries and had opportunities to apply necessary preventive measure more quickly. Particularly, while the difference between early and late-onset countries was significant until the 1000th case, it is observed that early-onset countries tend to close this difference until the date of the 10,000th case (earlyonset $=76.43 \pm 10.98$ late-onset $=78.36 \pm 5.30$ ). However; late-onset countries had more time to adapt prevent measures and apply them in population than early-onset country as Figure-1 also proves this point. This situation can be related to the idea that worldwide preventive measures and policies regarding it might not be adequate to struggle against the disease since there are still many uncertainties about the virus. This is supported by the finding that late-onset countries have shorter time intervals of key logarithmic growths. The finding that there are no significant differences between the SI scores of early and late-onset countries for the days of 1st, 10th, and 100th case leads us to think that countries take some time to see whether the virus tends to spread within a country region in order to implement preventive measures. In terms of the index rankings, Turkey ranks the first place in the 1st and 100th cases and ranks the second place in the 10th case.

The scope of measures is highly influenced by the economic structure and the social life habits of countries (31). Many studies showed that public health implementations such as cordons sanitaire, social distancing, home quarantine decreased the rate of new confirmed cases (32). While countries prefer some preventive measures such as school closures, limitations in workplaces, cancellation of public events, and restrictions on internal movement, there are some differences in terms of lockdown, restrictions regarding curfew, full closure of workplaces, and transportation restrictions. Restriction on international travel is the most early and common preventive measure. It is reported that the date of the first cases was delayed in countries that implemented international travel restrictions for those coming from both China and other countries where the cases were frequent (33). Nonetheless, it can be seen that there are some countries among late-onset countries that waited a certain amount of period for the emergence of the first case as it is also shown in Figure-1. Studies showing that the EU countries, where the second peak of the pandemic was occurred after China, were late for restriction of the international travels. Spain, Italy, Germany and France, which are among the countries with the highest number of cases at the time of our study, are the countries that have the widest transportation network both within the country and with each other (17). Delayed travel restrictions may have contributed to the rapid increase of cases in these countries. Turkey is the country that implemented most preventive measures before the emergence of the first confirmed case. The curfew for spesific groups such as the population who are above 65 years or below 20 years and for those living in metropolitan cities are specific examples of measures taken by Turkey (31).

There are some limitations regarding our study. Examining only the first 100 days of a pandemic might lead to bias because it is still an ongoing pandemic and it had not reached its peak by the time that the study was conducted. Moreover, the data of countries regarding the pandemic were not controlled whether they were referring to the related dates, but rather the information was collected from the situation reports of ECDC. Some information about the country data was not included if they are not included by OECD and UN. On the other hand, OxCGRT-20 is a dataset consisted of manually collected data and its limitations can be also seen as limitations of our study. The index that is used for the evaluation of measures might have shown some differences from the reality in terms of the existence of measures or the starting date of implementing those measures because the index constructs the data through governmental publications and news channels in which there might be some problems due to the reasons such as time or language barri- 
ers. The included information on the data set, SI point, and starting dates of measures was accepted to be true. While measures and SI point were evaluated based on limited criteria, their implementation levels were not examined. The confounding factors that can influence the transmission patterns of the pandemic such as geographic features, cultural factors, and economic factors could not be considered during the study. Furthermore, other preventive measures of countries which are not included in the data set were not considered. In the study, the whole data regarding the pandemic are official data which can be highly influenced by the case criteria of countries and their test policies. Because of this, it should be noted that the exact situation might be a bit different from our study.

In conclusion, late-onset countries benefited from the experiences of earlier onset countries and implemented measures. Despite of this, the emergence of cases and deaths could not be prevented. It is not adequate to examine only the preventive measures in order to explain the whole process because the transmission patterns of the pandemic are highly dependent upon country-specific dynamics. Accordingly, all variables that have an impact on the pandemic should be identified.

\section{Recommendations}

The effects of measures included in this study and of other measures taken by countries with their contributions on the prevention of the disease should be determined. Furthermore, new studies can be conducted in order to determine new possible measures. More studies should scrutinize the influence of each preventive measures on the pandemic data and also examine how changes in the pandemic data affect the patterns of preventive measures in order to understand more about the relationship between the preventive measures and the transmission patterns of the pandemic.

Funding Source: This research did not receive any funding.

Conflict of Interest: The authors declare no competing interest.

\section{REFERENCES}

1. World Health Organization. Novel Coronavirus (2019$\mathrm{nCoV}$ ) Situation Report - 1 [Internet]. [cited 2020 May 5]. Available from: https://www.who.int/docs/defaultsource/coronaviruse/situation-reports/20200121-sitrep1-2019-ncov.pdf?sfvrsn=20a99c10_4

2. WHO Director-General's remarks at the media briefing on 2019-nCoV on 11 February 2020 [Internet]. [cited 2020 May 5]. Available from: https://www.who.int/dg/speeches/ detail/who-director-general-s-remarks-at-the-media-briefing-on-2019-ncov-on-11-february-2020

3. World Health Organization. Novel Coronavirus (2019$\mathrm{nCoV})$ Situation Report-12 [Internet]. [cited 2020 May 5] Available from: https://www.who.int/docs/default-source/ coronaviruse/situation-reports/20200201-sitrep-12-ncov. pdf?sfvrsn=273c5d35_2

4. WHO Director-General's opening remarks at the media briefing on COVID-19 - 11 March 2020 [Internet]. [cited 2020 May 5]. Available from: https://www.who.int/dg/ speeches/detail/who-director-general-s-opening-remarksat-the-media-briefing-on-covid-19---11-march-2020

5. World Health Organization. Coronavirus Disease 2019 (COVID-19) Situation Repoert - 80 [Internet]. 2020 [cited 2020 May 5]. Available from: https://www.who.int/docs/ default-source/coronaviruse/situation-reports/20200409sitrep-80-covid-19.pdf?sfvrsn=1b685d64_6

6. European Centre for Disease Prevention and Control. Considerations relating to social distancing measures in response to the COVID-19 epidemic. Stockholm: ECDC; 2020

7. Organisation for Economic Co-operation and Development. Flattening the COVID-19 peak: Containment and mitigation policies. [Internet]. OECD; 2020. [cited 2020 May 5]. Available from: https://read.oecd-ilibrary.org/ view/?ref=124_124999-yt5ggxirhc\&title=Flattening_the_ COVID-19_peak-Containment_and_mitigation_policies

8. Nussbaumer-Streit B, Mayr V, Dobrescu AI, Chapman A Persad E, Klerings I, Wagner G, Siebert U, Christof C, Zachariah C, Gartlehner G. Quarantine alone or in combination with other public health measures to control COVID-19: a rapid review. Cochrane Database of Systematic Reviews; 2020(4). Art. No.: CD013574. doi:10.1002/14651858. CD013574.

9. Flaxman S, Mishra S, Gandy A, Unwin JT, Coupland H, Mellan TA, et al. Report 13: Estimating the number of infections and the impact of non-pharmaceutical interventions on COVID-19 in 11 European countries. Imperial College London; 2020 doi:10.25561/77731.

10. World Health Organization. COVID-19 Strategy Update 14 April 2020 [Internet]. 2020 [cited 2020 May 5]. Avail- 
able from: https://www.who.int/publications-detail/covid19-strategy-update---14-april-2020

11. World Health Organization. Considerations in adjusting public health and social measures in the context of COVID-19: interim guidance, 16 April 2020. [Internet]. 2020 [cited 2020 May 5]. Available from: https://apps.who.int/ iris/handle/10665/331773.

12. European Centre for Disease Prevention and Control. Download today's data on the geographic distribution of COVID-19 cases worldwide [Internet]. [cited 2020 May 5]. Available from: https://www.ecdc.europa.eu/en/publications-data/download-todays-data-geographic-distributioncovid-19-cases-worldwide

13. Organisation for Economic Co-operation and Development. OECD.Stat [Internet]. [cited 2020 Apr 22]. Available from: https://stats.oecd.org/

14. United Nations. World Population Prospects 2019 [Internet]. [cited 2020 Apr 23]. Available from: https://population.un.org/wpp/DataQuery/

15. Hale T, Webster S, Petherick A, Phillips T, Kira B. Oxford COVID-19 Government Response Tracker [Internet]. 2020 [cited 2020 Apr 26]. Available from: https://covidtracker. bsg.ox.ac.uk/

16. Hale T, Petherick A, Phillips T, Webster S. Variation in government responses to COVID-19. Work Pap [Internet]. 2020; [cited 2020 Apr 30]. Available from: https://www.bsg. ox.ac.uk/research/research-projects/coronavirus-government-response-tracker

17. Linka K, Peirlinck M, Sahli Costabal F, Kuhl E. Outbreak dynamics of COVID-19 in Europe and the effect of travel restrictions. Comput Methods Biomech Biomed Engin . 2020 May 5; 1-8. doi:10.1080/10255842.2020.1759560

18. Lau H, Khosrawipour V, Kocbach P, Mikolajczyk A, Ichii $\mathrm{H}$, Schubert J, et al. Internationally lost COVID-19 cases. J Microbiol Immunol Infect. 2020 Mar 14. doi: 10.1016/j. jmii.2020.03.013

19. Hellewell J, Abbott S, Gimma A, Bosse NI, Jarvis CI, Russell TW, et al. Feasibility of controlling COVID-19 outbreaks by isolation of cases and contacts. Lancet Glob Heal. $2020 \mathrm{Apr}$ 1;8(4):e488-96. doi:10.1016/S2214109X(20)30074-7

20. Qiu H, Tong Z, Ma P, Hu M, Peng Z, Wu W, et al. Intensive care during the coronavirus epidemic. Intensive Care Med. 2020; 46, 576-578. doi:10.1007/s00134-020-05966-y

21. Tartari F, Guglielmo A, Fuligni F, Pileri A. Changes in emergency service access after spread of COVID19 across Italy. J Eur Acad Dermatology Venereol JEADV. 2020;0-2. doi:10.1111/jdv.16553.

22. T.C. Sağlık Bakanlığı. COVID-19 (SARS-CoV-2 enfeksiyonu) rehberi, bilim kurulu çalışması [Internet]. [cited 2020 May 5]. Ankara; 2020. Available from: https://covid19bilgi.
saglik.gov.tr/depo/rehberler/COVID-19_Rehberi.pdf

23. Wu Z, McGoogan JM. Characteristics of and Important Lessons from the Coronavirus Disease 2019 (COVID-19) Outbreak in China: Summary of a Report of 72314 Cases from the Chinese Center for Disease Control and Prevention. JAMA - J Am Med Assoc. 2020;323(13):3-6. doi:10.1001/ jama.2020.2648

24. Lai CC, Wang CY, Wang YH, Hsueh SC, Ko WC, Hsueh PR. Global epidemiology of coronavirus disease 2019 (COVID-19): disease incidence, daily cumulative index, mortality, and their association with country healthcare resources and economic status. Int J Antimicrob Agents. 2020 Apr 1;55(4). doi: 10.1016/j.ijantimicag.2020.105946

25. Bialek S, Boundy E, Bowen V, Chow N, Cohn A, Dowling N, et al. Severe outcomes among patients with coronavirus disease 2019 (COVID-19) - United States, February 12-march 16, 2020. Morb Mortal Wkly Rep. 2020;69(12):343-6. doi:10.15585/mmwr.mm6912e2

26. T.C. Sağlık Bakanlığı. Türkiye'deki güncel durum [Internet]. [cited 2020 Apr 30]. Available from: https://covid19.saglik. gov.tr/

27. Yuan J, Li M, Lv G, Lu ZK, Lu ZK. Monitoring transmissibility and mortality of COVID-19 in Europe. Int J Infect Dis. 2020;95:311-5. doi: 10.1016/j.ijid.2020.03.050

28. T.C. Sağlık Bakanlığı. Bakan Koca, TBMM'de koronavirüs ile mücadeleye ilişkin sunum yaptı [Internet]. [cited 2020 May 3]. Available from: https://www.saglik.gov.tr/ TR,64544/bakan-koca-tbmmde-koronavirus-ile-mucadeleye-iliskin-sunum-yapti.html

29. Her M. How is COVID-19 affecting South Korea? What is our current strategy? Disaster Med Public Health Prep. 2020 May 233-5. doi:10.1017/dmp.2020.69.

30. Oh J, Lee J-K, Schwarz D, Ratcliffe HL, Markuns JF, Hirschhorn LR. National Response to COVID-19 in the Republic of Korea and Lessons Learned for Other Countries. Heal Syst Reform. 2020 Jan 1;6(1):e-1753464. doi:10.1080/2 3288604.2020 .1753464 .

31. Koçak Tufan Z, Kayaaslan B. Crushing the curve, the role of national and international institutions and policy makers in COVID-19 pandemic. Turk J Med Sci. 2020; 50: 495-508. doi: 10.3906/sag-2004-167

32. Pan A, Liu L, Wang C, Guo H, Hao X, Wang Q, et al. Association of Public Health Interventions with the Epidemiology of the COVID-19 Outbreak in Wuhan, China. JAMA - J Am Med Assoc. 2020. doi:10.1001/jama.2020.6130

33. Wells CR, Sah P, Moghadas SM, Pandey A, Shoukat A, Wang $\mathrm{Y}$, et al. Impact of international travel and border control measures on the global spread of the novel 2019 coronavirus outbreak. Proc Natl Acad Sci U S A. 2020 Mar 31;117(13):7504-9. doi:10.1073/pnas.2002616117 